\title{
Impaired glycogen synthesis in hepatocytes from Zucker fatty fa/fa rats: the role of increased phosphorylase activity
}

\author{
S. Aiston, M. Peak, L. Agius \\ Department of Diabetes and Metabolism, The Medical School, University of Newcastle upon Tyne, Newcastle upon Tyne, UK
}

\section{Abstract}

Aims/hypothesis. The Zucker fatty fa/fa rat develops hyperinsulinaemia, insulin-resistance and severe obesity as a result of a homozygous mutation in the leptin receptor gene. The aim was to characterise the metabolic defect(s) in hepatocytes from $f a / f a$ rats.

Methods. Glucose metabolism and key regulatory enzymes were investigated in hepatocytes from $\mathrm{fa} / \mathrm{fa}$ and $\mathrm{Fa} /$ ? rats after short-term culture in the absence of insulin.

Results. Hepatocytes from $f a / f a$ rats have higher glucokinase activity and expression of the glucokinase regulatory protein and higher rates of glycolysis and lipogenesis, but lower rates of glycogen synthesis than hepatocytes from $\mathrm{Fa} /$ ? controls. Insulin caused a similar stimulation of glycogen synthesis in hepatocytes from $f a / f a$ rats as in controls ( $>$ twofold) but did not restore the impaired glycogen synthesis in cells from $\mathrm{fa} / \mathrm{f} a$ rats. Adenovirus-mediated glucokinase overexpression stimulated glycogen synthesis and glycolysis but aggravated rather than abolished the relative impairment of glycogen synthesis in cells from $f a / f a$ rats. Inhibition of glycolysis with 2,5-anhydromannitol, an inhibitor of glycolysis and gluconeogenesis, increased glucose 6-phosphate concentrations and glycogen synthesis in hepatocytes from $\mathrm{Fal}$ ? and $f a / f a$ rats but did not restore the impaired glycogen synthesis in cells from $f a / f a$ rats. Hepatocytes from $f a / f a$ rats had a higher activity of phosphorylase $a$ in the basal state and after incubation with insulin or glucagon and higher total phosphorylase.

Conclusion/interpretation. The increased activity of phosphorylase is a major contributing factor to the impaired glycogen synthesis in hepatocytes from $\mathrm{fa} /$ fa rats and could contribute to the lipogenic state by a glycogenolytic-glycolytic-lipogenic pathway. [Diabetologia (2000) 43: 589-597]

Keywords Zucker, $\mathrm{fa} / \mathrm{fa}$ rat, leptin, insulin, phosphorylase, glycogen synthesis, glucokinase.
The Zucker fatty $(f a / f a)$ rat is homozygous for a mutation in the leptin receptor gene [1, 2] and develops pronounced hyperinsulinaemia and severe obesity with relatively mild hyperglycaemia [3-6]. It is considered to be a good model for the early stage of

Received: 24 November 1999 and in revised form: 17 January 2000

Corresponding author: L. Agius, Department of Diabetes and Metabolism, School of Clinical Medical Sciences, Medical School, University of Newcastle upon Tyne, Newcastle upon Tyne NE2 4HH, UK

Abbreviations: MEM, Minimum essential medium; G6P, glucose 6-phosphate.
Type II (non-insulin-dependent) diabetes mellitus because it shows both hepatic and peripheral insulin resistance [4-8]. The hepatic abnormalities of genetic animal models of obesity due to either leptin deficiency (ob/ob mouse) or leptin-receptor defects ( $\mathrm{fa} /$ $f a$ rat and $d b / d b$ mouse) are thought to be similar to the defect(s) in Type II diabetes and accordingly their pathophysiological characteristics were studied in detail before the cloning of the genes for leptin and its receptor $[9,10]$. Recent studies have identified the short-term effects of leptin on hepatic metabolism when given in vivo [11,12] and the direct effects of leptin on the perfused liver or differentiated hepatocytes in vitro [13-15]. 
Hepatic insulin resistance in $f a / f a$ rats is evident from impaired suppression of hepatic glucose production during euglycaemic clamps [4, 5], lack of suppression or transient stimulation of hepatic glucose production during an oral glucose tolerance test [6] and resistance to stimulation of glycogen synthesis by insulin after feeding [8]. Defective regulation of hepatic glucose production or hepatic glycogen synthesis by insulin in vivo could be due to changes in circulating hormones that oppose or potentiate the effects of insulin [16] or to defects (receptor or metabolic) in responsiveness of hepatocytes to hormones. The aim of the present study was to investigate the metabolic defect(s) in hepatocytes from fatty $(f a / f a)$ rats maintained in short-term primary culture in the absence of insulin to allow recovery from the shortterm effects of hormonal perturbations in vivo.

\section{Materials and methods}

Materials. Glucose 6-phosphate dehydrogenase (Leuconostoc mesenteroides), phosphorylase kinase and other enzymes were from Sigma Chemical (St. Louis, Mo., USA). We obtained $\left[\mathrm{U}-{ }^{14} \mathrm{C}\right]$ glucose, $\left[2-{ }^{3} \mathrm{H}\right]$ glucose, $\left[3-{ }^{3} \mathrm{H}\right]$ glucose, UDP $[1-$ $\left.{ }^{3} \mathrm{H}\right]$ glucose from New England Nuclear (Boston, Mass., USA). Sources of other reagents were as described previously [14].

Rats. Zucker rats (lean, $F a /$ ? and fatty, $f a / f a$ ) were obtained from Harlan Olac (Bicester, UK) at 6 weeks of age and were used between 9 and 11 weeks (female rats) or between 10 and 11 weeks (male rats). Body weights for lean $\mathrm{Fa} /$ ? rats were $186 \pm 10$ (female, $n=5$ ) and $260 \pm 5$ (male, $n=10$ ) and for $f a /$ $f a$ rats $340 \pm 27$ (female, $n=5)$ and $392 \pm 11$ (male, $n=10$ ) (means \pm SEM). Wistar rats (male, body wt. 180-250 g) were obtained from Bantin \& Kingman (Hull, UK). Standard rat chow and water were freely available. The work was done in accordance with the regulations of the United Kingdom Animal Scientific Procedures Act 1986.

Hepatocyte isolation and culture. Hepatocytes were isolated by collagenase perfusion of the liver [17]. They were suspended in minimum essential medium (MEM) containing $7 \%$ (v/v) neonatal calf serum and seeded in multi-well plates at a density of $4 \times 10^{4}$ cells $/ \mathrm{cm}^{2}$. After cell attachment $(4 \mathrm{~h})$ the medium was replaced by serum-free medium containing $10 \mathrm{nmol} / \mathrm{l}$ dexamethasone and the hepatocytes were cultured for $16-20 \mathrm{~h}$. For overexpression of glucokinase with recombinant adenovirus encoding rat liver glucokinase $[18,19]$ after cell attachment hepatocytes were incubated for $90 \mathrm{~min}$ in serum-free medium with varying titres of AdCMV-GKL as in [20]. The medium was then changed to MEM containing $10 \mathrm{nmol} / \mathrm{l}$ dexamethasone and the cells were cultured for 16-18 h. Unless otherwise indicated the medium contained $5 \mathrm{mmol} / \mathrm{l}$ glucose.

Metabolic studies. Incubations were either for $2 \mathrm{~h}$ or for $3 \mathrm{~h}$ in MEM containing the substrates indicated and either [U${ }^{14} \mathrm{C}$ ]glucose $(74 \mathrm{KBq})$ for determination of glycogen synthesis and lipogenesis or with $\left[2-{ }^{3} \mathrm{H}\right]$ glucose $(74 \mathrm{KBq})$ for determination of glucose phosphorylation or with or $\left[3-{ }^{3} \mathrm{H}\right]$ glucose $(74$ $\mathrm{KBq}$ ) for determination of glycolysis. On termination of the incubations the medium from experiments with $\left[{ }^{3} \mathrm{H}\right]$ glucose was collected into $0.1 \mathrm{~mol} / 1 \mathrm{HCl}$ for determination of ${ }^{3} \mathrm{H}_{2} \mathrm{O}$ [21]. Rates of formation of ${ }^{3} \mathrm{H}_{2} \mathrm{O}$ were linear with time for $3 \mathrm{~h}$ and are expressed as nmol of glucose detritiated $\cdot 3 \mathrm{~h}^{-1}$ (or $\left.\min ^{-1}\right) \cdot m g$ cell protein ${ }^{-1}$. Lactate accumulation in the medium was determined enzymically and is expressed as nmol. $3 \mathrm{~h}^{-1} \cdot \mathrm{mg}$ protein ${ }^{-1}$. Cellular glucose 6 -phosphate (G6P) was determined as in [21]. For determination of glycogen synthesis hepatocytes were washed with $0.9 \%$ saline and extracted in $0.1 \mathrm{~mol} / 1 \mathrm{NaOH}$. Extracts were deproteinised with trichloroacetic acid $(10 \%, w / v)$ containing glycogen carrier and radioactivity incorporated in glycogen determined as in [17]. Glycogen synthesis determined from the incorporation of ${ }^{14} \mathrm{C}$-glucose into glycogen was linear with time during $3 \mathrm{~h}$ and is expressed as nmol of glucose incorporated $3 \mathrm{~h}^{-1}\left(\right.$ or $\left.\mathrm{min}^{-1}\right) \cdot \mathrm{mg}$ of cell protein ${ }^{-1}$. Incorporation of ${ }^{14} \mathrm{C}$-glucose into lipid was determined as in [22] and protein was determined as in [23].

Enzyme activity determination. For determination of free and bound glucokinase activity hepatocyte monolayers were washed once with $0.9 \%$ saline and incubated in permeabilisation medium containing $300 \mathrm{mmol} / \mathrm{l}$ sucrose, $5 \mathrm{mmol} / \mathrm{l} \mathrm{MgCl}_{2}$, $3 \mathrm{mmol} / \mathrm{l} \mathrm{HEPES}, 2 \mathrm{mmol} / \mathrm{l}$ dithiothreitol, $0.04 \mathrm{mg} / \mathrm{ml}$ digitonin, $\mathrm{pH}$ 7.2. After 8 min the medium was collected for determination of free glucokinase activity and the bound activity was extracted as in [20]. Glucokinase was assayed by the glucose 6-phosphate dehydrogenase (Leuconostoc mesenteroides) linked assay [20]. Total glucokinase activity is expressed as milliunits/mg cell protein and the free activity is expressed as a percentage of total (free + bound) activity. Glucokinase regulatory protein was determined by western blotting (24). For determination of phosphorylase $a$ and glycogen synthase activity (active and total) hepatocyte monolayers were snap-frozen in liquid $\mathrm{N}_{2}$ and extracted as in [14]. Phosphorylase $a$ was assayed spectometrically using a Cobas-Bio Centrifugal Analyzer (Roche Diagnostics, Basel, Switzerland) [14]. Total phosphorylase was determined after conversion of phosphorylase $b$ to phosphorylase $a$ using phosphorylase kinase [25]. Glycogen synthase (active and total) was determined in the absence or presence of $10 \mathrm{mmol} / \mathrm{l} \mathrm{G6P}$, respectively [26]. Activities are expressed in milliunits/mg of cell protein and active glycogen synthase is also expressed as a fraction of total activity (-G6P: + G6P).

Expression of results. Results are expressed as means \pm SEM for the number of cell preparations indicated. Statistical analysis was by the Student's unpaired $t$ test for comparisons between $\mathrm{Fa} /$ ? and $\mathrm{fa} / \mathrm{fa}$ preparations and by the paired $t$ test for comparisons within the same preparations. A difference was considered to be statistically significant when $p$ was less than 0.05 .

\section{Results}

Increased glucokinase activity and glycolysis in hepatocytes from fa/fa rats. The activity of glucokinase and the expression of glucokinase regulatory protein after $16 \mathrm{~h}$ culture in serum-free medium were twofold higher in hepatocytes from female fatty $\mathrm{fa} / \mathrm{fa}$ rats than from $\mathrm{Fa} /$ ? controls (Table 1). Similar differences in glucokinase activity were observed between $f a / f a$ and $\mathrm{Fa} /$ ? hepatocytes from male rats (results not shown). Previous studies on fresh liver have also shown a twofold higher activity of glucokinase in $\mathrm{fa} /$ $f a$ rats than controls [27]. The fractional distribution 
Table 1. Glucokinase activity, regulatory protein expression and glucose metabolism in hepatocytes from female $\mathrm{Fa}$ ? ? and $\mathrm{fa} / \mathrm{fa}$ rats

\begin{tabular}{|c|c|c|}
\hline & $\mathrm{Fa} /$ ? Hepatocytes & $f a / f a$ Hepatocytes \\
\hline $\begin{array}{l}\text { Glucokinase activity } \\
\text { (milli-units/mg) }\end{array}$ & $12.4 \pm 1.6$ & $28.9 \pm 1.3^{\mathrm{b}}$ \\
\hline $\begin{array}{l}\text { Regulatory protein } \\
\text { (arbitrary units) }\end{array}$ & $3.5 \pm 0.5$ & $7.9 \pm 0.7^{\mathrm{a}}$ \\
\hline $\begin{array}{l}\text { Detritiation of } \\
{\left[3-{ }^{3} \mathrm{H}\right] \text { glucose }}\end{array}$ & $367 \pm 6$ & $609 \pm 48^{\mathrm{a}}$ \\
\hline Lactate formation & $243 \pm 9$ & $522 \pm 21^{b}$ \\
\hline $\begin{array}{l}{ }^{14} \mathrm{C} \text {-Glucose conversion } \\
\text { to lipid }\end{array}$ & $13 \pm 0.3$ & $22 \pm 1^{\mathrm{a}}$ \\
\hline $\begin{array}{l}{ }^{14} \mathrm{C}-\text {-Glucose conversion } \\
\text { to glycogen }\end{array}$ & $14 \pm 2$ & $10 \pm 1^{\mathrm{a}}$ \\
\hline
\end{tabular}

Glucose metabolism was determined from a 3-h incubation with $10 \mathrm{mmol} / \mathrm{l}$ glucose and $\left[3-{ }^{3} \mathrm{H}\right]$ glucose or $\left[\mathrm{U}-{ }^{14} \mathrm{C}\right]$ glucose. Rates are expressed as nmol of glucose metabolised or lactate formed $\cdot 3 \mathrm{~h}^{-1} \cdot \mathrm{mg}$ protein ${ }^{-1}$. Means \pm SEM, for four to five experiments. ${ }^{\mathrm{a}} p<0.05,{ }^{\mathrm{b}} \mathrm{p}<0.005$ relative to $\mathrm{Fa} /$ ?

of glucokinase between free and bound states which is a measure of the enzyme in the cytoplasm and nuclear compartments, respectively increased with increasing glucose concentration in agreement with previous findings on Wistar rats [20] and was similar in hepatocytes from $f a / f a$ and $F a /$ ? rats at high glucose concentration but at low glucose was slightly higher in cells from $f a / f a$ rats (Fig. 1). Hepatocytes from $f a /$ $f a$ rats had higher rates of glycolysis (detritiation of $\left[3-{ }^{3} \mathrm{H}\right]$ glucose and formation of lactate) and lipogenesis from ${ }^{14} \mathrm{C}$-glucose but lower rates of glycogen synthesis than cells from $\mathrm{Fa} /$ ? controls (Table 1).

Glucokinase overexpression stimulates glycogen synthesis and glycolysis but aggravates the impaired glycogen synthesis in hepatocytes from fa/fa rats. Because glycogen synthesis in hepatocytes is very sensitive to small changes in glucokinase activity [20] the finding that hepatocytes from $f a / f a$ rats have impaired glycogen synthesis despite a twofold increase in glucokinase activity was surprising. We therefore investigated the relation between glucokinase activity (by overexpressing the enzyme using recombinant adenovirus) and glycolysis and glycogen synthesis in hepatocytes from $f a / f a$ and $F a /$ ? rats. Glucokinase overexpression resulted in increased glycolysis and glycogen synthesis (Fig.2) in cells from both $\mathrm{fa} / \mathrm{fa}$ and $F a /$ ? rats. The increment in glycogen synthesis was, however, smaller in hepatocytes from $f a / f a$ rats and glucokinase overexpression did not correct the defect in cells from $f a / f a$ rats (Fig. 2).

Glycogen synthesis, synthase and phosphorylase activities. Insulin caused a similar stimulation of glycogen synthesis in hepatocytes from female $\mathrm{fa} / \mathrm{fa}$ and $\mathrm{Fa} /$ ? rats ( 3 and 2.5-fold, respectively) and did not abolish

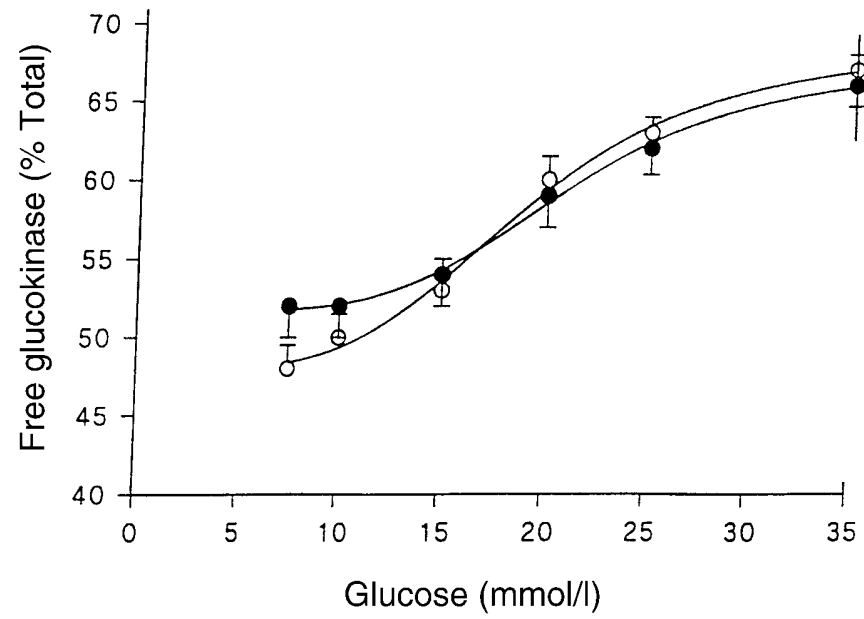

Fig. 1. Distribution of glucokinase in hepatocytes from Zucker rats. Hepatocytes from female $f a / f a,(O)$ or $F a /$ ? $(\bigcirc)$ rats were cultured for $16 \mathrm{~h}$ in MEM. They were then incubated for $60 \mathrm{~min}$ with the glucose concentrations indicated. Free and bound glucokinase activity were determined as described in the Methods Section and free activity is expressed as \% of total activity. Means \pm SEM, $n=5$

the lower rate of glycogen synthesis in cells from $\mathrm{fa} /$ $f a$ rats (Fig.3). The concentration of insulin that caused the half-maximum effect was similar $(\sim 0.1$ $\mathrm{nmol} / \mathrm{l}$ ) in $f a / f a$ and $\mathrm{Fa} /$ ? cells (Fig. 3). Similar differences in rates of glycogen synthesis were observed in hepatocytes from male rats (Fig.4) and male rats were used in the rest of this study. The lower rate of glycogen synthesis was associated with a lower fractional activity of glycogen synthase (Fig.4) and a higher activity of phosphorylase $a$ (Fig. 4). Insulin decreased $(p<0.02)$ the activity of phosphorylase $a$ by $38 \pm 4 \%$ and $30 \pm 6 \%$ in cells from $F a /$ ? and $f a / f a$ rats, respectively and glucagon increased activity $(p<0.002)$ by $9.3 \pm 1.5$-fold and $9.6 \pm 0.4$-fold, respectively. In the presence of insulin or glucagon the activity of phosphorylase $a$ was higher $(p<0.01)$ by 2.7 or 2.3-fold in cells from $f a / f a$ rats (Fig. 4). To investigate whether the higher activity of phosphorylase $a$ can be explained by a higher activity of total phosphorylase we determined the activity of phosphorylase after activation with phosphorylase kinase in cells extracted at the start of the culture. Cells from $f a / f a$ rats had a higher $(p<0.001)$ activity of total phosphorylase (Fig. 4).

Reciprocal control of glycolysis and glycogen synthesis in hepatocytes from Wistar rats. Because hepatocytes from $f a / f a$ rats have higher rates of glycolysis but lower rates of glycogen synthesis at an equivalent glucokinase activity than $\mathrm{Fa} /$ ? controls (Fig.2), we tested the possibility that impaired glycogen synthesis could be due to increased partitioning of G6P, derived from glucose, towards glycolysis. We determined whether known inhibitors of glycolysis (gluco- 


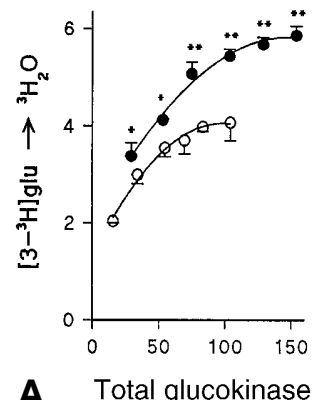

A Total glucokinase

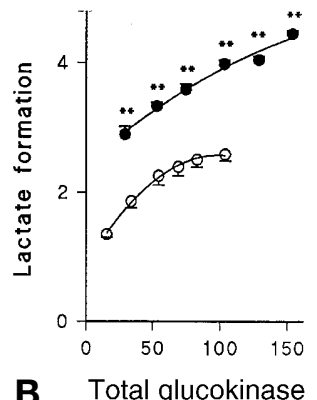

B Total glucokinase

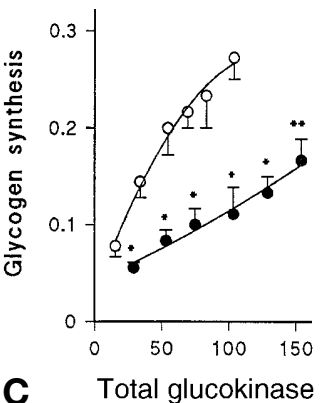

Fig. 2 A-C. Stimulation of glucose metabolism by glucokinase overexpression. Hepatocytes from female $\mathrm{fa} / \mathrm{fa}$, (O) or $\mathrm{Fa} /$ ? (O) rats were treated with varying titres of AdCMV-GKL to induce glucokinase overexpression and cultured for $16 \mathrm{~h}$ in MEM. They were then incubated for $3 \mathrm{~h}$ in fresh medium containing $10 \mathrm{mmol} / \mathrm{l}$ glucose and either $\left[3{ }^{3} \mathrm{H}\right]$ glucose for determination of glycolysis from formation of ${ }^{3} \mathrm{H}_{2} \mathrm{O}(\mathbf{A})$ or accumulation of lactate $(\mathbf{B})$ or $\left[\mathrm{U}_{-}{ }^{14} \mathrm{C}\right]$ glucose for determination of glycogen synthesis $(\mathbf{C})$. Rates of glucose metabolism or formation of lactate are expressed as $\mathrm{nmol} \cdot \mathrm{min}^{-1} \cdot \mathrm{mg}$ protein ${ }^{-1}$ and are plotted against total glucokinase activity (milliunits $/ \mathrm{mg}$ protein). Means \pm SEM, for $n=4, * p<0.05$; ** $p<0.005 \mathrm{fa} / \mathrm{fa}$ vs $\mathrm{Fa} /$ ?

neogenic precursors, ethanol and palmitate [28]) affect glycogen synthesis. Glycogen synthesis from glucose $(20 \mathrm{mmol} / \mathrm{l})$ was stimulated by gluconeogenic substrates which inhibit glycolysis but not glucose phosphorylation and by palmitate and ethanol which inhibit both glycolysis and glucose phosphorylation (Table 2). The latter inhibition is due to inhibition of glucokinase translocation [29]. Stimulation of glycogen synthesis by palmitate occurs over a range of glucose concentrations (Fig.5). There are at least two possible explanations for the increase in glycogen synthesis. There is either partitioning of G6P derived from glucose to glycogen synthesis when glycolysis is inhibited or in the presence of increased gluconeogenesis, as would occur with palmitate and gluconeogenic substrates, G6P derived from gluconeogenesis activates glycogen synthase. To eliminate the latter possibility we used 2,5-anhydromannitol which is a potent inhibitor of both glycolysis [30] and gluconeogenesis [31, 32]. It also inhibits glycogenolysis [32] but with a lower potency than for glycolysis and has no effect on glycogenolysis at $100 \mu \mathrm{mol} / \mathrm{l}$ (S. Aiston, L. Agius, unpublished results). It was therefore used in subsequent studies on hepatocytes from $f a / f a$ and $\mathrm{Fa} /$ ? rats.

2,5-Anhydromannitol stimulates glycogen synthesis but does not correct the defect in hepatocytes from fal fa rats. Glycolysis was inhibited by 2,5 -anhydromannitol $(p<0.001)$ in both $f a / f a$ and $F a /$ ? cells by $67 \%$ with half-maximum effect at about $50 \mu \mathrm{mol} / \mathrm{l}$ (Fig. 6) and it stimulated $(p<0.01)$ glycogen synthesis by $50 \%$ or $33 \%$ in cells from fa/fa or Fa/? rats also with
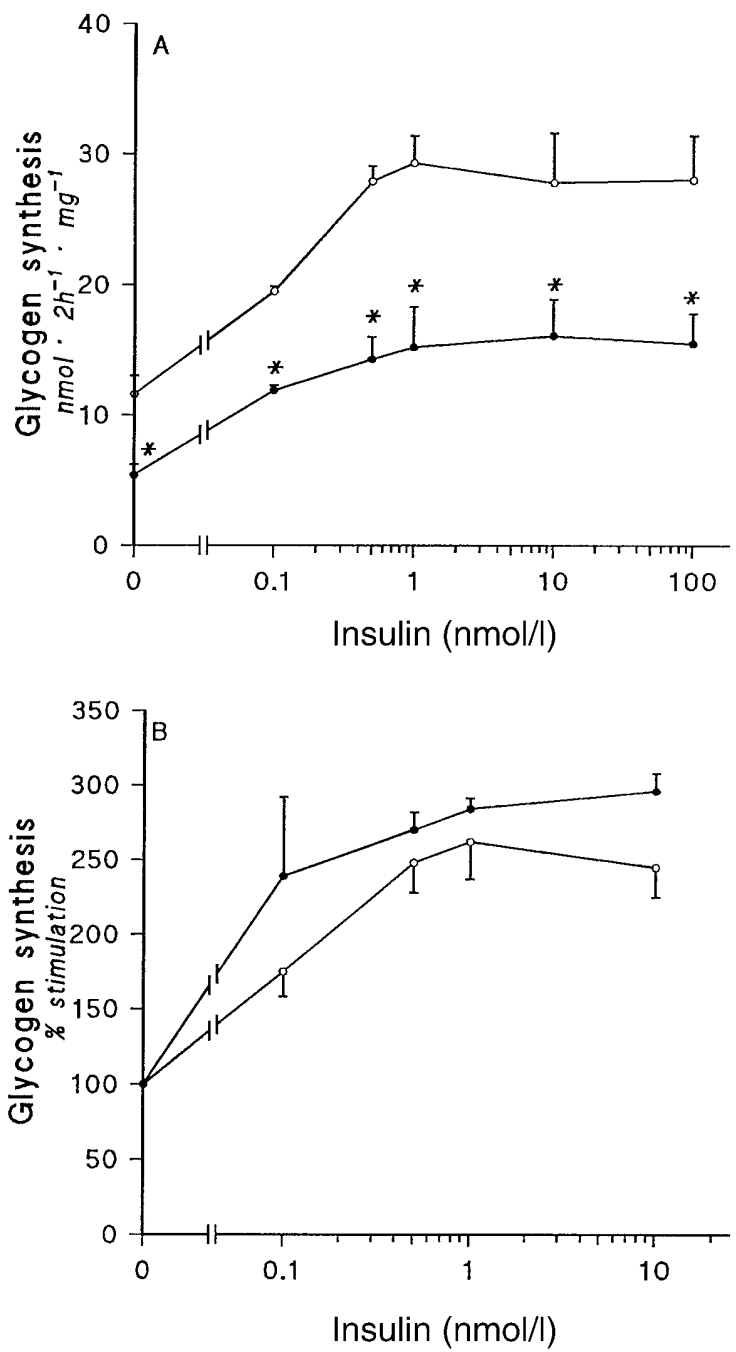

Fig. 3 A, B. Stimulation of glycogen synthesis by insulin. Hepatocytes from female $f a / f a,(O)$ or $F a /$ ? $(\bigcirc)$ rats were cultured for $16 \mathrm{~h}$ in MEM. They were then incubated for $2 \mathrm{~h}$ in MEM containing $10 \mathrm{mmol} / \mathrm{l}$ glucose, $\left[\mathrm{U}-{ }^{14} \mathrm{C}\right]$ glucose and the concentrations of insulin indicated. A Rates of glycogen synthesis expressed as nmol of glucose incorporated into glycogen $\cdot 2 \mathrm{~h}^{-1} \cdot \mathrm{mg}$ protein ${ }^{-1}$. B Values as a percentage of respective controls. Means \pm SEM, $n=4,{ }^{*} p<0.05, f a / f a$ vs $F a /$ ?

half-maximum effect at about $50 \mu \mathrm{mol} / \mathrm{l}$ (Fig. 6). Glucose phosphorylation was slightly inhibited $(25 \%$, $p<0.01$ ) by $250 \mu \mathrm{mol} / 1$ 2,5-anhydromannitol (Fig. 6) and the G6P content was increased by threefold and twofold in cells from $\mathrm{fa} / \mathrm{fa}$ and $\mathrm{Fa} /$ ? rats, respectively 

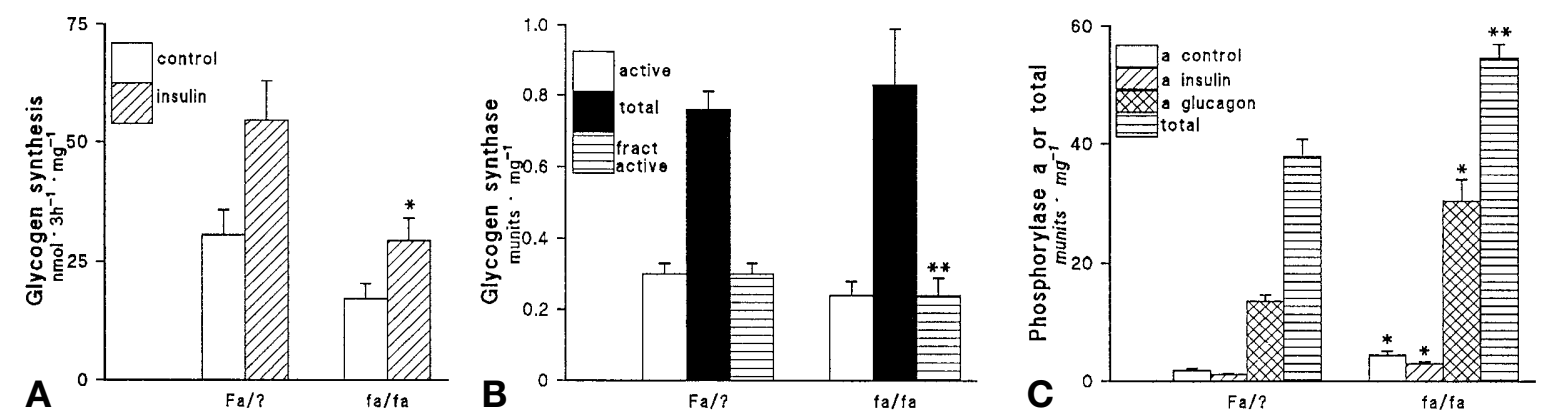

Fig.4A-C. Glycogen synthase and phosphorylase activity. Hepatocytes from male $f a / f a$ or $F a /$ ? rats were cultured for $16 \mathrm{~h}$ in MEM and were then incubated in medium containing $15 \mathrm{mmol} / \mathrm{l}$ glucose and the hormones indicated. A Glycogen synthesis in the absence $(\square)$ or presence (ख) of $10 \mathrm{nmol} / \mathrm{l}$ insulin. B Active $(\square)$ and total activity ( $\square$ ) of glycogen synthase (mU/mg) and fractional activity (每) (active/total) in the absence of hormones. C Phosphorylase $a$ in hepatocytes incubated with $10 \mathrm{nmol} / \mathrm{l}$ insulin (ख) (4 h) or $10 \mathrm{nmol} / \mathrm{l}$ glucagon (ख) (30 min) and total phosphorylase ( control. Means \pm SEM, $n=5$ or $6 ; * p<0.05 ; * * p<0.005 \mathrm{fa} / \mathrm{fa}$ vs $\mathrm{Fa}$ ?

(Fig. 6). Because the increase in G6P was not associated with an increase in glucose phosphorylation it is most likely due to the inhibition of glycolysis. Although G6P concentrations were similar in $f a / f a$ and $\mathrm{Fa} /$ ? hepatocytes treated with 2,5-anhydromannitol (Fig. 6), rates of glycogen synthesis were significantly lower in $f a / f a$ cells (Fig. 6). When glycolysis and glycogen synthesis were expressed as a fraction of glucose phosphorylation to account for the higher glucokinase activity in $f a / f a$ cells, partitioning of glucose towards glycolysis was similar in hepatocytes from $f a / f a$ and $F a /$ ? rats (Fig. 7). Partitioning towards glycogen synthesis was, however, twofold lower in cells from $\mathrm{fa} / \mathrm{fa}$ rats and this difference was not abolished by 2,5-anhydromannitol (Fig. 7).

\section{Discussion}

The Zucker fatty $f a / f a$ rat is widely used as a model for Type II diabetes. Its metabolic syndrome is the combined result of the leptin-receptor defect, the hyperphagia and secondary endocrine abnormalities. In this study we investigated the metabolic defect(s) in hepatocytes from $\mathrm{fa} / \mathrm{fa}$ rats maintained in short-term culture $(<24 \mathrm{~h})$ in insulin-free medium. This experimental system enables the study of glucose metabolism and short-term effects of insulin in defined substrate and hormone conditions [33]. Hepatocytes from $f a / f a$ rats show a similar responsiveness of glycogen synthesis to insulin compared with controls in terms of sensitivity and degree of stimulation. This is consistent with previous findings that hepatic insulin receptors are not down-regulated in 10-week-old $\mathrm{fa}$ / $f a$ rats [34]. Hepatic insulin resistance in vivo has been inferred in 10 to 11 -week-old $f a / f a$ rats, based on similar rates of glycogen deposition after feeding as in controls despite higher blood insulin, glucose and lactate concentrations [8]. This could be explained by the impaired glycogen synthesis from glucose in hepatocytes from fa/fa rats observed in this study. Four lines of evidence indicate that this is not due to a defect in the maximum capacity for glycogen synthesis. Firstly, the total activity of glycogen synthase was similar in hepatocytes from $f a / f a$ and $F a /$ ? rats. Secondly, the activity of glucokinase, which has a high control strength on glycogen synthesis [20], was higher in hepatocytes from $\mathrm{fa} / \mathrm{fa}$ rats and the ratio of glucokinase to regulatory protein was unchanged.
Table 2. Effects of inhibitors of glycolysis on glycogen synthesis in hepatocytes from Wistar rats

\begin{tabular}{llll}
\hline & $\begin{array}{l}\text { Glucose } \\
\text { phosphorylation }\end{array}$ & Glycolysis & $\begin{array}{l}\text { Glycogen } \\
\text { Synthesis }\end{array}$ \\
\hline Additions & & & \\
None & $3.0 \pm 0.2$ & $2.89 \pm 0.61$ & $0.51 \pm 0.02$ \\
$0.5 \mathrm{mmol} / \mathrm{l}$ palmitate & $2.7 \pm 0.2^{\mathrm{a}}$ & $1.19 \pm 0.30^{\mathrm{a}}$ & $0.81 \pm 0.07^{\mathrm{a}}$ \\
$2.5 \mathrm{mmol} / \mathrm{l}$ ethanol & $2.4 \pm 0.2^{\mathrm{b}}$ & $1.39 \pm 0.25^{\mathrm{a}}$ & $0.91 \pm 0.09^{\mathrm{a}}$ \\
$10 \mathrm{mmol} / \mathrm{l}$ pyruvate & $2.9 \pm 0.3$ & $0.51 \pm 0.05^{\mathrm{b}}$ & $1.07 \pm 0.05^{\mathrm{b}}$ \\
$2 \mathrm{mmol} / \mathrm{l}$ lactate & $2.9 \pm 0.4$ & $2.05 \pm 0.18^{\mathrm{b}}$ & $0.75 \pm 0.07^{\mathrm{a}}$ \\
$10 \mathrm{mmol} / \mathrm{l}$ lactate & $2.9 \pm 0.3$ & $1.25 \pm 0.23^{\mathrm{b}}$ & $0.94 \pm 0.05^{\mathrm{b}}$ \\
\hline
\end{tabular}

Glucose metabolism was determined from a 2-h incubation with $20 \mathrm{mmol} / \mathrm{l}$ glucose, $2 \%$ BSA and the additions indicated and $\left[2-{ }^{3} \mathrm{H}\right]$ glucose (phosphorylation), $\left[3-{ }^{3} \mathrm{H}\right]$ glucose (glycolysis) or $\left[\mathrm{U}-{ }^{14} \mathrm{C}\right]$ glucose (glycogen synthesis). Rates are expressed as nmol of glucose metaboli$\mathrm{sed} \cdot \mathrm{min}^{-1} \cdot \mathrm{mg}$ protein ${ }^{-1}$. Means $\pm \mathrm{SEM}$, for four to eight experiments, ${ }^{\mathrm{a}} p<0.05,{ }^{\mathrm{b}} p<0.005$ relative to controls 

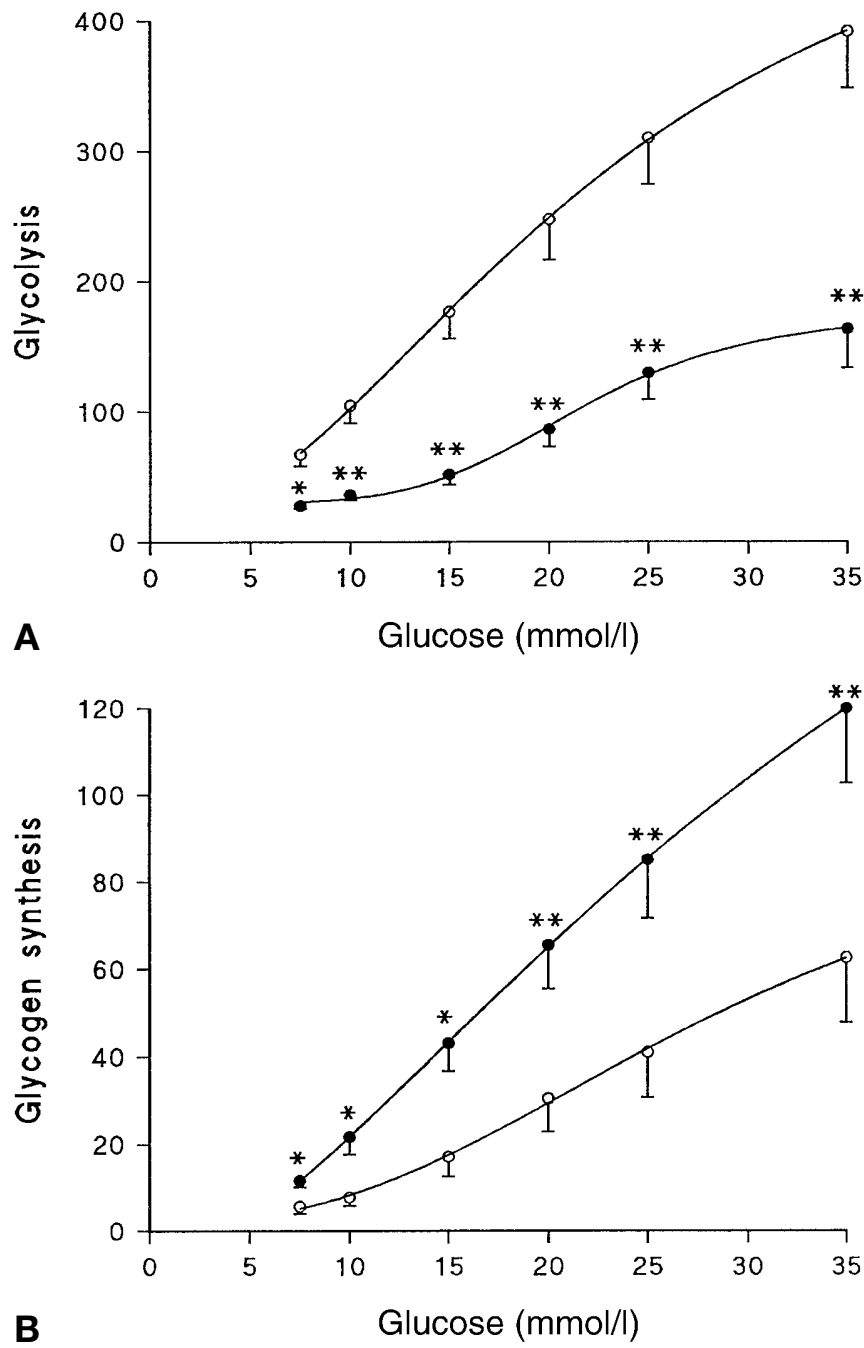

Fig.5A, B. Reciprocal effects of palmitate on glycolysis and glycogen synthesis. Hepatocytes from Wistar rats were cultured for $16 \mathrm{~h}$ in MEM. They were then incubated for $2 \mathrm{~h}$ in MEM with the glucose concentrations indicated and 2\% BSA in either the absence $(\bigcirc)$ or presence $(O)$ of $0.5 \mathrm{mmol} / \mathrm{l} \mathrm{pal}-$ mitate with either $\left[3-{ }^{3} \mathrm{H}\right]$ glucose $(\mathbf{A})$ or $\left[\mathrm{U}_{-}{ }^{14} \mathrm{C}\right]$ glucose $(\mathbf{B})$. Glycolysis (formation of ${ }^{3} \mathrm{H}_{2} \mathrm{O}$ ) or glycogen synthesis (incorporation of $\left[\mathrm{U}_{-}{ }^{14} \mathrm{C}\right]$ glucose into glycogen) are expressed as $\mathrm{nmol} \cdot 2 \mathrm{~h}^{-1} \cdot \mathrm{mg}$ protein $^{-1}$, means $\pm \mathrm{SEM}, \quad n=5, * p<0.05$; $* * p<0.005$ palmitate vs control

Thirdly, insulin caused a similar fold stimulation of glycogen synthesis in $\mathrm{fa} / \mathrm{fa}$ cells as in controls. Fourthly, glucokinase overexpression caused a pronounced increase in glycogen synthesis in hepatocytes from $f a / f a$ rats. The main metabolic characteristics of hepatocytes from $f a / f a$ rats that could account for the impaired glycogen synthesis are the increased glycolysis, the higher activity of phosphorylase (active and total) and the lower fractional activity of synthase. The latter could be secondary to inhibition of synthase phosphatase by the increase in phosphorylase $a$ [35].

The hypothesis that an increase in glycolytic capacity accounts for the impaired glycogen synthesis is consistent with the finding that several inhibitors of glycolysis including gluconeogenic precursors, palmitate and ethanol have inverse effects on glycolysis and glycogen synthesis. The finding that anhydromannitol, a potent inhibitor of glycolysis, did, however, not reverse the impaired glycogen synthesis in hepatocytes from $f a / f a$ rats does not support the hypothesis that the impaired glycogenesis in $f a / f a$ cells is due to the high glycolysis.

The higher activity of phosphorylase $a$ seems the most likely explanation for the impaired glycogen synthesis in hepatocytes from $f a / f a$ rats. We cannot exclude the possibility that there could be differences in the short-term control of phosphorylase by covalent modification between hepatocytes from $\mathrm{fa} / \mathrm{fa}$ and $\mathrm{Fa} /$ ? rats. Based on the higher activity of total phosphorylase in hepatocytes from $f a / f a$ and the similar change in phosphorylase $a$ in the presence of glucagon or insulin the higher activity of total phosphorylase seems, however, the most likely explanation for the higher activity of phosphorylase $a$. An increased activity of phosphorylase $a$ can lead to decreased glycogen accumulation by three mechanisms. Firstly, through increased degradation of glycogen. Secondly, through a decrease in the glycation state of the glycogen primer, glycogenin, which could make it a poorer substrate for glycogen synthase [36]. Thirdly, through allosteric inhibition of synthase phosphatase by phosphorylase $a$ [35].

Our finding that the increased activity of phosphorylase could be the main metabolic defect in hepatocytes from $f a / f a$ rats is consistent with the increased hepatic glucose production by $f a / f a$ rats in the basal state and after a meal $[5,6]$. An increased activity of phosphorylase (active and total) was reported in the $d b / d b$ mouse which is also homozygous for a leptinreceptor mutation [37, 38]. Notably, only liver and not muscle phosphorylase is increased in $d b / d b$ mice [38]. A higher activity of phosphorylase $a$ was observed in hepatocytes from $f a / f a$ rats (compared with $\mathrm{Fa} /$ ? control rats) during incubation with phenylephrine or vasopression [39]. It was not established however, that this was due to an increase in total phosphorylase [40].

We have shown that culture of hepatocytes with leptin for between $4 \mathrm{~h}$ and $16 \mathrm{~h}$ decreases the activity of phosphorylase $a$ in the basal state but not after activation by glucagon suggesting that leptin decreases the activation state of phosphorylase [14]. We have confirmed from direct determination of total phosphorylase with phosphorylase kinase that culture of hepatocytes with leptin for $24 \mathrm{~h}$ is associated with a decrease in phosphorylase $a$ without a change in total phosphorylase (S. Aiston and L. Agius, unpublished results). We cannot, however, exclude the possibility that longer-term exposure of hepatocytes to leptin in vivo down-regulates total phosphorylase activity. Thus the higher activity of phosphorylase in cells 

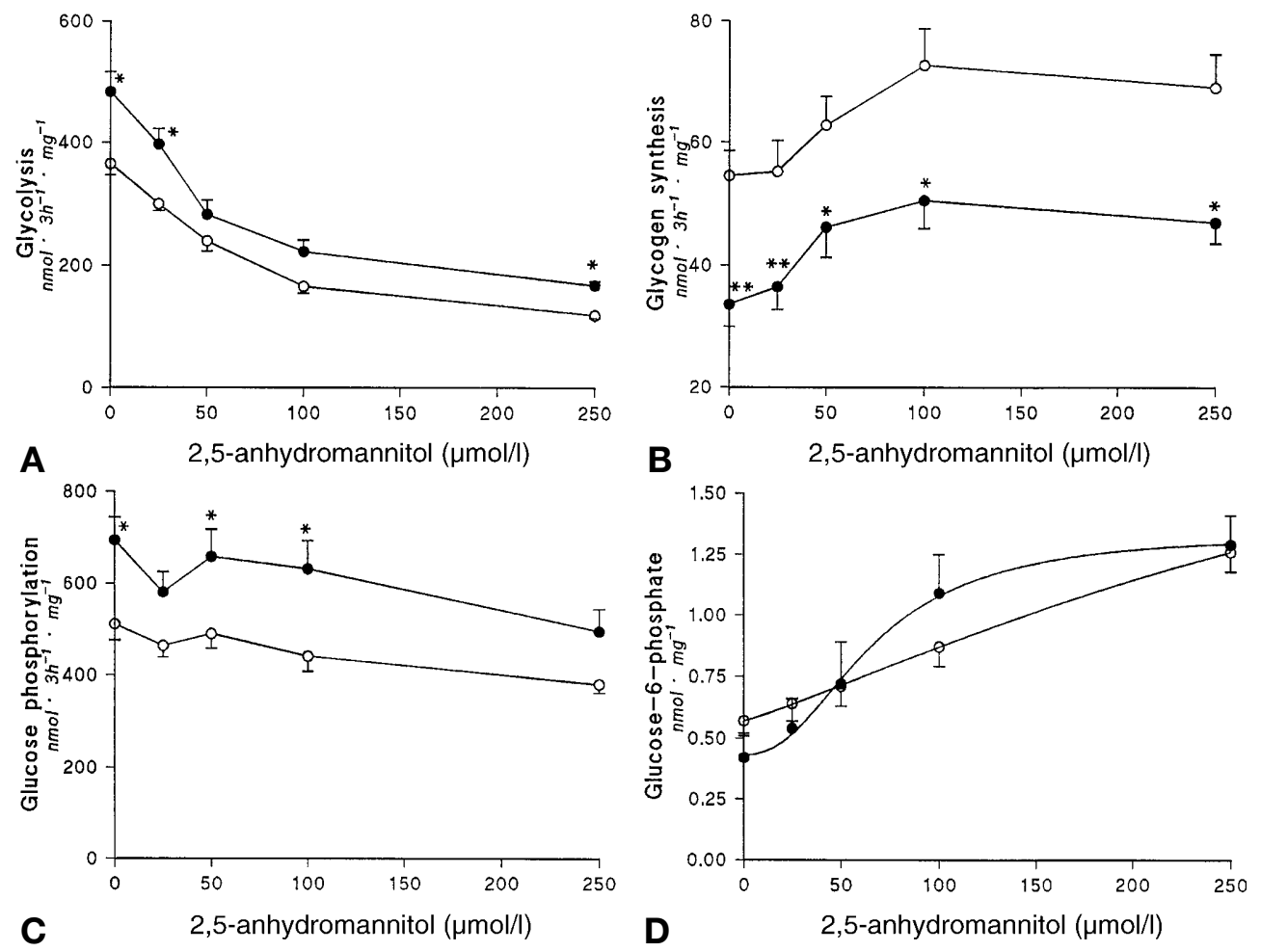

Fig. 6A-D. Reciprocal effects of 2,5-anhydromannitol on glycolysis and glycogen synthesis. Hepatocytes from male $\mathrm{fa} / \mathrm{fa}$ (O) or $\mathrm{Fa} /$ ? $(\mathrm{O})$ rats were cultured for $16 \mathrm{~h}$ in MEM. They were then incubated for $3 \mathrm{~h}$ with $20 \mathrm{mmol} / \mathrm{l}$ glucose and the concentrations of 2,5-anhydromannitol indicated and either: $\left[3-{ }^{3} \mathrm{H}\right]$ glucose $(\mathbf{A}),\left[\mathrm{U}-{ }^{14} \mathrm{C}\right]$ glucose $(\mathbf{B})$ or $\left[2-{ }^{3} \mathrm{H}\right]$ glucose $(\mathbf{C})$ for determination of glycolysis, glycogen synthesis or glucose phosphorylation respectively, expressed as nmol of glucose metabolised $\cdot 3 \mathrm{~h}^{-1} \cdot \mathrm{mg}$ protein $^{-1}$. Glucose 6-phosphate (D) was determined after $2 \mathrm{~h}$ and is expressed as nmol $\cdot \mathrm{mg}$ protein $^{-1}$. Means \pm SEM, $n=4, * p<0.05 ; * * p<0.005$ fa/fa vs Fa/?

Fig. 7 A, B. Partitioning of glucose between glycogen synthesis and glycolysis. For experimental details see Fig. 6. Glycolysis (A) and glycogen synthesis (B) in hepatocytes from $f a / f a(\mathbf{O})$ and $\mathrm{Fa} /$ ? $(\mathrm{O})$ rats are expressed as a percentage of the rate of glucose phosphorylation. Means \pm SEM, $n=4, * p<0.05$; ** $p<0.005 \mathrm{fa} / \mathrm{fa}$ vs $\mathrm{Fa} /$ ?

from $f a / f a$ rats could be due to either the chronic "leptin-resistant" state in vivo or to secondary endocrine factors. Because insulin increases the stability of phosphorylase mRNA [41] the possibility that the increased insulin in vivo is a contributing factor to the high phosphorylase activity cannot be excluded. The higher activity of glucokinase and expression of the regulatory protein in hepatocytes from $f a / f a$ rats are consistent with the high insulin concentrations in vivo, because transcription of glucokinase [42] and expression of the regulatory protein [43] are both increased by insulin.

Increased phosphorylase in $f a / f a$ hepatocytes could lead to increased flux through a glycogenolytic and glycolytic pathway. Evidence supporting such a pathway was provided by studies on phosphorylase overexpression in muscle cells which showed increased glycolysis and lipid accumulation [44]. Similar studies in hepatocytes could clarify the role of liver phosphorylase in a glycolytic/lipogenic pathway.
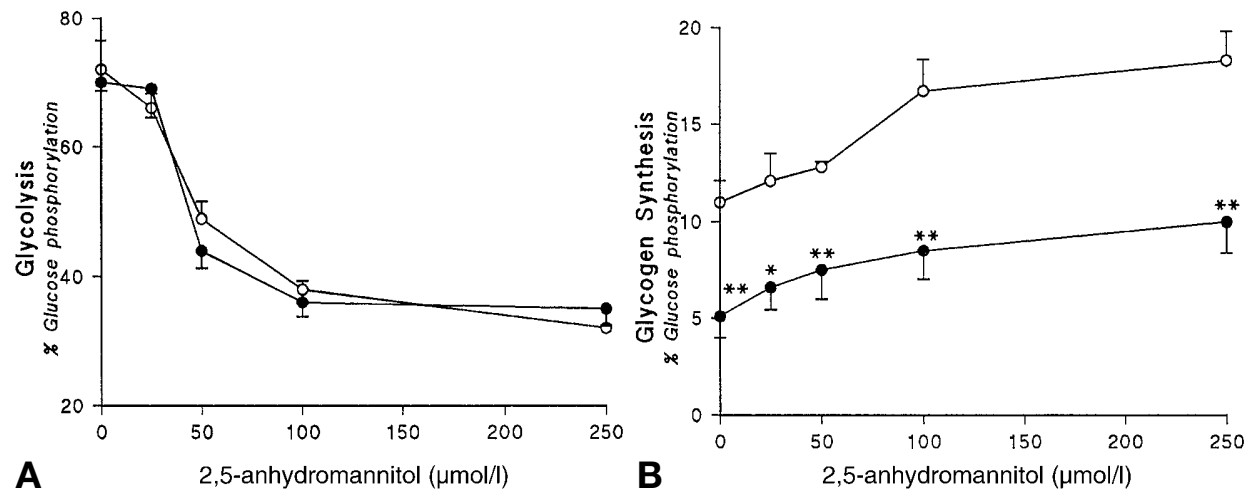
Because hepatocytes from $f a / f a$ rats also have increased lipogenesis, the metabolic syndrome in hepatocytes from $f a / f a$ rats seems analogous to that observed after phosphorylase overexpression in muscle [44]. A hepatic glycogenolytic/glycolytic/lipogenic pathway in a hyperphagic leptin-resistant state could be a mechanism for diverting excess dietary carbohydrate to triacylglycerol when the glycogen stores are repleted. Conversely, the function of leptin in decreasing phosphorylase activity [14] could be to favour glycogen storage relative to triacylglycerol stores. A clear understanding of the function of phosphorylase in determining the balance between glycogen storage and conversion to triacylglycerol is essential for establishing whether phosphorylase is a suitable target for pharmacological intervention.

Acknowledgements. This work was supported by grants from the Juvenile Diabetes Foundation International grant No 195002 and the Medical Research Council. We thank Mr. A. Simm for expert technical assistance.

\section{References}

1. Phillips MS, Liu Q, Hammond HA et al. (1996) Leptin receptor missense mutation in the fatty Zucker rat. Nat Genet 13: 18-19

2. Chua SC, White DW, Wu-Peng XS et al. (1996) Phenotype of fatty due to Gln269Pro mutation in the leptin receptor (Lepr). Diabetes 45: 1141-1143

3. Bray GA (1997) The Zucker-fatty rat: a review. Fed Proc 36: 148-153

4. Terrettaz J, Jeanrenaud B (1983) In vivo hepatic and peripheral insulin resistance in genetically obese (fa/fa) rats. Endocrinology 112: 1346-1351

5. Terrettaz J, Assimacopoulos-Jeannet F, Jeanrenaud B (1986) Severe hepatic and peripheral insulin resistance as evidenced by euglycaemic clamps in genetically obese fa/ fa rats. Endocrinology 118: 674-678

6. Rohner-Jeanrenaud F, Proietto J, Ionescu E, Jeanrenaud B (1986) Mechanism of abnormal glucose tolerance of genetically obese fa/fa rats. Diabetes 35: 1350-1355

7. Ionescu E, Sauter JF, Jeanrenaud B (1985) Abnormal glucose tolerance in genetically obese (fa/fa) rats. Am J Physiol 248:E500-E506

8. Van de Werve G, Jeanrenaud B (1987) The onset of liver glycogen synthesis in fasted-refed lean and genetically obese (fa/fa) rats. Diabetologia 30: 169-174

9. Zhang Y, Proenca R, Maffei M, Barone M, Leopold L, Friedman JM (1994) Positional cloning of the mouse obese gene and its human homologue. Nature 372: 425-432

10. Flier JS (1997) Leptin expression and action: new experimental paradigms. Proc Natl Acad Sci USA 94: 4242-4245

11. Rossetti L, Massillon D, Barzilai N et al. (1997) Short term effects of leptin on hepatic gluconeogenesis and in vivo insulin action. J Biol Chem 272: 27758-27763

12. Liu L, Karkanias GB, Morales JC et al. (1998) Intracerebroventricular leptin regulates hepatic but not peripheral glucose fluxes. J Biol Chem 273: 31160-31167

13. Cohen SM, Werrmann JG, Tota MT (1998) ${ }^{13}$ C NMR study of the effects of leptin treatment on kinetics of hepatic intermediary metabolism. Proc Natl Acad Sci USA 95: 7385-7390
14. Aiston S, Agius L (1999) Leptin enhances hepatic glycogen storage by inhibition of phosphorylase and exerts an additive effect with insulin. Diabetes 48: 15-20

15. Nemecz M, Preininger K, Englisch R et al. (1999) Acute effect of leptin on hepatic glycogenolysis and gluconeogenesis in perfused rat liver. Hepatology 29: 166-172

16. Rohner-Jeanrenaud F, Jeanrenaud B (1988) Abnormal regulation of pancreatic glucagon secretion in obese fa/fa rats. Diabetologia 31: 235-240

17. Agius L, Peak M, Alberti KGMM (1990) Regulation of glycogen synthesis from glucose and glucongeogenic precursors in periportal and perivenous rat hepatocytes. Biochem J 266: 91-102

18. Becker TC, Noel RJ, Johnson JH et al. (1996) Differential effects of overexpressed glucokinase and hexokinase I in isolated islets. Evidence for functional segregation of the high and low Km enzymes. J Biol Chem 271: 390-394

19. O'Doherty RM, Lehman DL, Seoane J, Gomez-Foix AM, Guinovart JJ, Newgard CB (1996) Differential metabolic effects of adenovirus-mediated glucokinase and hexokinase I overexpression in rat primary hepatocytes. J Biol Chem 271: 20524-20530

20. Agius L, Peak M, Newgard CB, Gomez-Foix AM, Guinovart JJ (1996) Evidence for a role of glucose-induced translocation of glucokinase in the control of hepatic glycogen synthesis. J Biol Chem 273: 30479-30486

21. Agius L (1997) Involvement of glucokinase translocation in the mechanism by which resorcinol inhibits glycolysis in hepatocytes. Biochem J 325: 667-673

22. Bligh EG, Dyer WJ (1959) A rapid method of total lipid extraction and purification. Can J Biochem Physiol 37: 912-917

23. Clifton PM, Chang K, McKinnon AM (1988) Development of an automated Lowry Method for the cobas bio centrifugal analyzer. Anal Biochem 172: 165-168

24. Agius L, Peak M, Van Schaftingen E (1995) The regulatory protein of glucokinase binds to the hepatocyte matrix but unlike glucokinase does not translocate during substrate stimulation. Biochem J 309: 711-713

25. Stalmans W, De Wulf H, Hue L, Hers HG (1974) The sequential inactivation of glycogen phosphorylase and activation of glycogen synthetase in liver after administration of glucose to mice and rats. Eur J Biochem 41: 127-134

26. Thomas JA, Schlender KK, Larner J (1968) A rapid filter paper assay for UDP-glucose-glycogen glucosyltransferase, including an improved biosynthesis of UDP- ${ }^{14} \mathrm{C}$-glucose. Anal Biochem 25: 486-499

27. Speydevold SO, Greenbaum AL, Baquer NZ, McLean P (1978) Adaptive responses of enzymes of carbohydrate and lipid metabolism to dietary manipulation in genetically obese Zucker rats (fa/fa). Eur J Biochem 89: 329-339

28. Hue L, Maisin L, Rider MH (1988) Palmitate inhibits liver glycolysis. Biochem J 251: 541-545

29. Agius L (1994) Control of glucokinase translocation in rat hepatocytes by sorbitol and the cytosolic redox state. Biochem J 298: 237-243

30. Riquelme PT, Kneer NM, Wernette-Hammond ME, Lardy HA (1985) Inhibition by 2,5-anhydromannitol of glycolysis in isolated rat hepatocytes and in Ehrlich ascites cells. Proc Natl Acad Sci USA 82: 78-82

31. Riquelme PT, Wenette-Hammond ME, Kneer NM, Lardy HA (1983) Regulation of carbohydrate metabolism by 2,5anhydromannitol. Proc Natl Acad Sci USA 80: 4301-4305

32. Hanson RL, Ho RS, Wiseberg JJ, Simpson R, Younathan ES, Blair JB (1984) Inhibition of gluconeogenesis and glycogenolysis by 2,5-anhydro-D-mannitol. J Biol Chem 259: 218-223 
33. Peak M, Rochford JJ, Borthwick AC, Yeaman SJ, Agius L (1998) Signalling pathways involved in the stimulation of glycogen synthesis by insulin in rat hepatocytes. Diabetologia 41: 16-25

34. Clark JB, Clark CM (1982) Age-related changes in insulin receptor regulation in liver membranes from Zucker fatty rats. Endocrinology 111: 964-969

35. Bollen M, Keppens S, Stalmans W (1998) Specific features of glycogen metabolism in the liver. Biochem J 336: 19-31

36. Cao Y, Skurat AV, De Paoli-Roach A, Poach PJ (1993) Initiation of glycogen synthesis. Control of glycogenin by glycogen phosphorylase. J Biol Chem 268: 21717-21721

37. Roesler WJ, Khandelwal RL (1986) Quantitation of glycogen synthase and phosphorylase protein in mouse liver: correlation between enzymatic protein and enzyme activity. Arch Biochem Biophys 244: 397-407

38. Board M, Hadwen M, Johnson LN (1995) Effects of novel analogues of D-glucose on glycogen phosphorylase activities in crude extracts of liver and muscle. Eur J Biochem 228: 753-761
39. Van de Werve G, Massillon D (1990) Altered regulation of glycogen metabolism by vasopressin and phenylephrine in hepatocytes from insulin-resistant obese (fa/fa) rats. Biochem J 269: 795-799

40. Van de Werve G (1990) Fasting enhances glycogen synthase activation in hepatocytes from insulin-resistant genetically obese fa/fa rats. Biochem J 269: 789-794

41. Rao PV, Pugazhenthi S, Khandelwal RL (1995) The effects of streptozotocin induced diabetes and insulin supplementation on expression of the glycogen phosphorylase gene in rat liver. J Biol Chem 270: 24955-24960

42. Iynedjian PJ (1993) Mammalian glucokinase and its gene. Biochem J 293: 1-13

43. Vandercammen A, Van Schaftingen E (1993) Species and tissue distribution of the regulatory protein of glucokinase. Biochem J 294: 551-555

44. Baqué S, Guinovart JJ, Gomez-Foix AM (1996) Overexpression of muscle glycogen phosphorylase in cultured human musscle fibres causes increased glucose consumption and nonoxidative glucose disposal. J Biol Chem 271: 2594-2598 